\title{
Microstructure of pasteurized process cheese manufactured from vacuum condensed and ultrafiltered milk1
}

\author{
Vikram V. MISTRY*, Ashraf N. HASSAN, Mayur R. ACHARYA** \\ Midwest Dairy Foods Research Center, Dairy Science Department, South Dakota State University, \\ Brookings SD 57007, USA
}

Received 28 March 2006 - Accepted 19 September 2006

\begin{abstract}
Milk standardized to $45 \mathrm{~g} \cdot \mathrm{kg}^{-1}$ protein (UF1 and CM1) and $60 \mathrm{~g} \cdot \mathrm{kg}^{-1}$ protein (UF2 and CM2) using ultrafiltered milk (150 g.kg-1 protein) or vacuum condensed milk (120 g.kg-1 protein) was used for manufacturing Cheddar cheese. Pasteurized Process cheeses were manufactured using a 1:1 blend of 18-week and 30-week Cheddar cheese. The moisture content of the Process cheeses ranged from 393 to $402 \mathrm{~g} \cdot \mathrm{kg}^{-1}$. Fat content was the highest in the control cheese $\left(350 \mathrm{~g} \cdot \mathrm{kg}^{-1}\right)$ and the lowest in UF2 (316 g. $\left.\mathrm{kg}^{-1}\right)$. Microstructure of cheeses was observed using cryo-scanning electron microscopy. Fat globules of different sizes embedded in the continuous protein network were observed. Whereas, a porous structure with relatively large pores was noted in the control cheese, more compact protein masses were observed in cheeses made from concentrated milk. Fat globules in all cheeses were surrounded by cavities. Firmness of cheese was associated with less porous (compact) protein network. Large areas of dense highly fused protein were observed in UF2 cheeses, which showed the highest resistance to compression (highest firmness). Fractures in the protein network were observed as the firmness of cheese increased. Such fractures reduced the ability of protein network to entrap fat and increased the level of free oil. Appendages connecting fat globules to protein network were seen in cheese containing low amounts of free oil which indicated good emulsifying properties. The continuous less rigid protein structure with good emulsifying properties (the presence of appendages connecting protein network to fat globules) produced cheese with increased meltability. This study shows that the application of concentrated milks for Cheddar cheese-making influences Process cheese functionality and structure.
\end{abstract}

ultrafiltration / condensing / Process cheese / microstructure

摘要 - 真空和超滤浓缩牛乳生产的巴氏杀菌熔化干酪的微观结构。采用 5 组不同处理的原 料奶生产切达干酪, 实验组为超滤浓缩 (150 g. $\mathrm{kg}^{-1}$ 蛋白质) 和真空浓缩 $\left(120 \mathrm{~g} \cdot \mathrm{kg}^{-1}\right.$ 蛋白质) 的牛乳分别标准化到蛋白质含量为 $45 \mathrm{~g} \cdot \mathrm{kg}^{-1}$ (UF1 和 CM1) 和 $60 \mathrm{~g} \cdot \mathrm{kg}^{-1}$ (UF2 和 CM2), 对 照组为普通鲜牛奶。将成熟 18 周和 30 周的切达干酪 $1: 1$ 混合后加工成巴氏杀菌熔化干酪。 熔化干酪的水分含量为 $393 \sim 402 \mathrm{~g} \cdot \mathrm{kg}^{-1}$ 。对照组的脂肪含量最高 $\left(350 \mathrm{~g} \cdot \mathrm{kg}^{-1}\right)$, UF2 组的脂 肪含量最低 $\left(316 \mathrm{~g} \cdot \mathrm{kg}^{-1}\right)$ 。通过低温扫描电子显微镜可以观察到不同形状的脂肪球被包裹在 连续的蛋白质网络中, 而且发现对照组和实验组干酪样品在微观结构上存在着显著地差 异。对照组样品呈现着较大孔径的多孔结构, 而由浓缩奶生产的干酪中蛋白质结合的非常

\footnotetext{
* Corresponding author (通讯作者): vikram.mistry@sdstate.edu

** Current address: Wells' Dairy, 1 1st Street S.W., Le Mars, IA 51031, USA.

1 Published with the approval of director of the South Dakota Agricultural Experiment Station as Publication Number 3497 of the Journal Series. This research was sponsored, in part, by the Midwest Dairy Foods Research Center, Brookings, SD and Midwest Dairy Association, St. Paul, MN.
} 
紧密。在所有的干酪样品中脂肪球的周围都出了现窄的孔隙。蛋白质网络的孔洞越小，干 酪的质地越紧密。在硬度最高的 UF2 干酪中可以观察到大面积的、密集的、高度融合的蛋 白质结构，UF2 干酪的抗压缩性最高。当干酪硬度增加到一定程度时出现了蛋白质网络断 裂的现象, 这种断裂现象会导致蛋白质网络对脂肪球包裹能力下降进而增加游离脂肪的含 量。在游离脂肪含量低的手酪样品中，可以观察到脂肪和蛋白质网络融为一体，这种干酪 的乳化性能非常好, 具有这种蛋白质结构的干酪其熔融性非常好。实验证明由浓缩乳生产 的切达干酪会影响其熔化干酪特性和微观结构。

\section{超滤 / 浓缩 / 熔化干酪 / 微观结构}

Résumé - Microstructure de fromage fondu pasteurisé fabriqué à partir de lait concentré sous vide ou ultrafiltré. Du lait standardisé en protéines à $45 \mathrm{~g} \cdot \mathrm{kg}^{-1}$ (UF1 et CM1) et à $60 \mathrm{~g} \cdot \mathrm{kg}^{-1}$ (UF2 et CM2) à l'aide de lait ultrafiltré (150 g. $\mathrm{kg}^{-1}$ de protéines) ou concentré sous vide $\left(120 \mathrm{~g} \cdot \mathrm{kg}^{-1} \mathrm{de}\right.$ protéines) a été utilisé pour fabriquer du cheddar. Des fromages fondus pasteurisés ont été fabriqués à partir d'un mélange $1: 1$ de cheddar de 18 semaines et de 30 semaines d'affinage. La teneur en eau des fromages allait de $393 \mathrm{à} 402 \mathrm{~g} \cdot \mathrm{kg}^{-1}$. La teneur en matière grasse la plus élevée a été obtenue dans le fromage témoin $\left(350 \mathrm{~g} \cdot \mathrm{kg}^{-1}\right)$ et la plus faible dans le fromage UF2 $\left(316 \mathrm{~g} \cdot \mathrm{kg}^{-1}\right)$. La microstructure des fromages a été observée par cryo-microscopie électronique à balayage (cryo-SEM). Des globules gras de différentes tailles, imbriqués dans le réseau protéique continu, ont été observés. Alors qu'une structure poreuse, avec des pores relativement larges, a été observée dans les fromages témoins, des masses protéiques plus compactes sont apparues dans les fromages obtenus avec le lait concentré. Dans tous les fromages, les globules gras étaient entourés de cavités. La fermeté du fromage était associée à un réseau protéique moins poreux (compact). De larges zones de protéines denses très fusionnées ont été observées dans les fromages UF2 présentant la plus grande résistance à la compression (fermeté maximale). Avec l'augmentation de la fermeté des fromages, des fractures sont apparues dans le réseau protéique, réduisant sa capacité à inclure la matière grasse et augmentant le taux de matière grasse libre. Des joints de connexion reliant les globules gras au réseau protéique ont été observés dans le fromage ayant le moins de matière grasse libre, et donc de bonnes propriétés émulsifiantes. La structure protéique continue la moins rigide, avec de bonnes propriétés émulsifiantes (présence de joints de connexion reliant réseau protéique et globules gras), a conduit à un fromage présentant une aptitude à la fonte accrue. Cette étude montre que l'utilisation de lait concentré pour la fabrication de cheddar affecte les propriétés fonctionnelles et la structure du fromage fondu.

ultrafiltration / concentration / fromage fondu / microstructure

Abbreviation key: $\mathbf{C M}=$ condensed milk, $\mathbf{U F}=$ ultrafiltered milk.

\section{INTRODUCTION}

Ultrafiltration and vacuum condensing are common concentration techniques used in cheese making. These techniques produce milks of distinctly different properties that also influence the characteristics of cheese from such milks [1]. The quality attributes of Process cheese are greatly influenced by the composition and nature of base cheeses. Therefore, the use of concentrated milk in making the base cheese would affect the characteristics of Process cheese [2]. Electron microscopic studies offer opportunities for studying the structural characteristics of cheese as they relate to other physico-chemical properties $[3,8]$. In conventional scanning electron microscopy, sample preparation techniques induce artifacts and make it difficult to relate the microstructure to physical and functional properties of the product. With this technique, fat is extracted prior to microscopic observation. Hence, fat in cheese is represented only by cavities caused by the removal of fat. This does not allow direct observation of fat globules or the study of the interaction between fat globules and the protein matrix. Cryo-scanning electron microscopy allows observation of fully hydrated specimen without the need for fat extraction [4]. This technique 


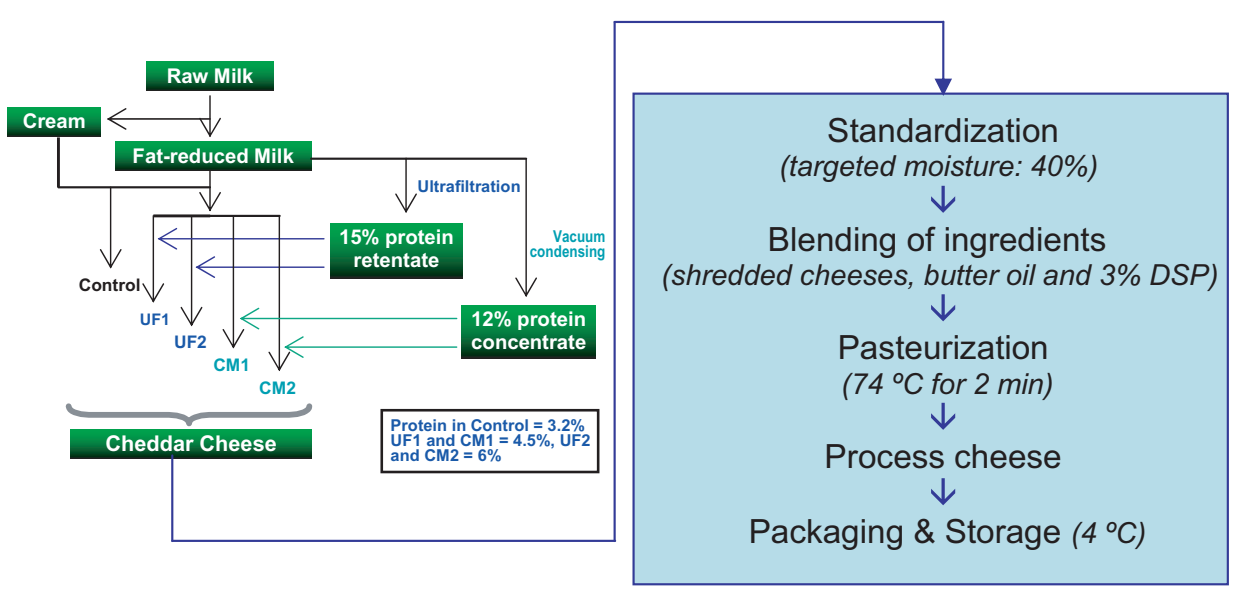

Figure 1. Manufacture of pasteurized Process cheese from condensed and ultrafiltered milks. Treatment: $\mathrm{C}=$ Control; UF1 $=45 \mathrm{~g} \cdot \mathrm{kg}^{-1}$ protein ultrafiltered milk; UF2 $=60 \mathrm{~g} \cdot \mathrm{kg}^{-1}$ protein ultrafiltered milk; $\mathrm{CM} 1=45 \mathrm{~g} \cdot \mathrm{kg}^{-1}$ protein condensed milk; $\mathrm{CM} 2=60 \mathrm{~g} \cdot \mathrm{kg}^{-1}$ protein condensed milk. UF = ultrafiltration; $\mathrm{CM}=$ condensing; $\mathrm{DSP}=$ disodium phosphate duohydrate.

is suitable for studying specimen with high moisture levels [7]. The objective of this study was to relate the physical and functional properties of pasteurized Process cheese manufactured from milk concentrated by vacuum condensation or ultrafiltration to its microstructure as observed with cryo-scanning electron microscopy.

\section{MATERIALS AND METHODS}

\subsection{Pasteurized Process cheese manufacture}

A mixture of 18-week and 30-week Cheddar cheeses from five different treatments ( $\mathrm{C}$, Control), ultrafiltered milk with $45 \mathrm{~g} \cdot \mathrm{kg}^{-1}$ protein (UF1) and $60 \mathrm{~g} \cdot \mathrm{kg}^{-1}$ protein (UF2) and vacuum condensed milk with $45 \mathrm{~g} \cdot \mathrm{kg}^{-1}$ protein (CM1) and $60 \mathrm{~g} \cdot \mathrm{kg}^{-1}$ protein (CM2) were manufactured (Fig. 1) as described earlier [1]. Formulation of Process cheese was done using young and aged Cheddar cheese, butteroil and $3 \%$ disodium phosphate (DSP) to obtain approximately $400 \mathrm{~g} \cdot \mathrm{kg}^{-1}$ moisture in the final product. Batch size was $16 \mathrm{~kg}$. A Damrow single auger direct steam injection cheese cooker (Model No. 84-062, Damrow, Fond du Lac, WI) was used for Process cheese manufacture. Steam injection was done at $4.2 \mathrm{~kg} \cdot \mathrm{cm}^{-2}$. Temperature of pasteurization was $77^{\circ} \mathrm{C}$ and holding time was $2 \mathrm{~min}$. At the end of the holding period, the Process cheese was packaged in half-gallon plastic containers, inverted and stored at $4{ }^{\circ} \mathrm{C}$ until analyzed [2]. Composition of the cheeses is in Table I.

\subsection{Cryo-stage scanning electron microscopy}

Cheese samples, $1 \times 3 \times 5 \mathrm{~mm}$, were taken from within the Process cheese block. Each cheese piece was mounted vertically into a slot in a copper cryo-stub [4]. Samples were then frozen by immersion into liquid nitrogen slush cooled to about $-210^{\circ} \mathrm{C}$ under vacuum. The frozen samples were transferred under a protective frost shroud into a preparation chamber attached to the SEM chamber. Samples were fractured by striking it with a pre-cooled razor blade and then etched at $-80{ }^{\circ} \mathrm{C}$ for $10 \mathrm{~min}$. The etched samples were cooled to $-150^{\circ} \mathrm{C}$, sputter coated with about $200 \mathrm{~nm}$ gold under vacuum, and then transferred onto the scanning electron microscope cryo-stage 
Table I. Composition ${ }^{1}$ of Process cheese.

\begin{tabular}{lcccccc}
\hline & \multicolumn{5}{c}{ Treatment $^{2}$} & \\
\cline { 2 - 5 } Parameter & $\mathrm{C}$ & $\mathrm{UF} 1$ & $\mathrm{UF} 2$ & $\mathrm{CM} 1$ & $\mathrm{CM} 2$ & SEM $^{3}$ \\
\hline Moisture $\left(\mathrm{g} \cdot \mathrm{kg}^{-1}\right)$ & $394^{\mathrm{b}}$ & $393^{\mathrm{b}}$ & $394^{\mathrm{b}}$ & $393^{\mathrm{b}}$ & $402^{\mathrm{a}}$ & 4.0 \\
Protein $\left(\mathrm{g} \cdot \mathrm{kg}^{-1}\right)$ & 196 & 212 & 226 & 201 & 215 & 2.7 \\
Fat $\left(\mathrm{g} \cdot \mathrm{kg}^{-1}\right)$ & $350^{\mathrm{a}}$ & $337 \mathrm{c}$ & $316^{\mathrm{d}}$ & $346^{\mathrm{b}}$ & $317^{\mathrm{d}}$ & 2.8 \\
$\mathrm{pH}$ & 6.0 & 6.0 & 6.1 & 6.1 & 6.2 & 1.4 \\
\hline
\end{tabular}

a,b,c,d Means in the same row without common superscripts are significantly $(P \leq 0.05)$ different. Means with no superscripts do not have significant interaction between method and level of concentration.

${ }^{1}$ Acharya and Mistry, [2]. Mean of six replicates.

2 Treatment: $\mathrm{C}=\mathrm{Control} ; \mathrm{UF} 1=45 \mathrm{~g} \cdot \mathrm{kg}^{-1}$ protein ultrafiltered milk; UF2 $=60 \mathrm{~g} \cdot \mathrm{kg}^{-1}$ protein ultrafiltered milk; CM1 $=45 \mathrm{~g} \cdot \mathrm{kg}^{-1}$ protein condensed milk; $\mathrm{CM} 2=60 \mathrm{~g} \cdot \mathrm{kg}^{-1}$ protein condensed milk.

$3 \mathrm{SEM}=$ Standard error of means.

for observation at $5 \mathrm{kV}$ accelerating voltage using a Hitachi S3500N scanning electron microscope (Nissei Sangyo America, Ltd, Gaithersburg, MD, USA) equipped with an Emitech K1150 Cryogenic Preparation System (Houston, TX, USA).

\section{RESULTS AND DISCUSSION}

In an earlier study, it was demonstrated that concentrating milk by vacuum condensing or ultrafiltration has a direct impact on the properties of Process cheeses [2]. Scanning electron microscopic examination demonstrated that fat globules of different sizes were embedded in the continuous protein network in all cheeses (Fig. 2). Distinct differences were observed between the control cheese and cheeses manufactured from concentrated milks; in control cheeses a porous structure with relatively large pores was observed (Fig. 2a), whereas in cheeses from concentrated milks more compact protein masses were observed (Figs 2b-e). The microscopic observations correlated well with rheological characteristics reported earlier ([2], Tab. II). The firmer the cheese, the less porous (more compact) the structure. In the firmest cheese, (UF2, Fig. 2e), a very compact protein network was observed. Joshi et al. [5] observed a smoothening of partskim Mozzarella cheese surface, as seen by scanning electron microscopy, with a reduction in calcium of cheese. Though the calcium content of Process cheeses was not measured, that of base Cheddar showed a lowest level in control cheeses relative to those from concentrated milks [1]. Higher calcium cheeses (such as those from concentrated milks) have poor meltability because of lower hydration and increased protein-protein aggregation [5]. This is manifested as a "tight" microstructure.

The protein network, although compact, was more granular in CM2 than in UF2 cheeses. The large areas of the dense fused protein in UF2 were probably responsible for the high firmness. Fractures in the protein network were observed as the firmness of cheese increased (Fig. 3a and b). The fractures interfered with the continuity of the protein network (Fig. 3a), reduced the ability of cheese to entrap fat and increased the level of free oil (notice the partial detachment of fat globules as a result of the fracture in the network in Fig. 3a, and the level of free oil in Tab. II).

In convention scanning electron microscopy fat is extracted from cheese prior to microscopic observations, hence an interpretation of the role of fat on cheese structure is based on the assumption that certain cavities in the cheese structure represent fat [6]. Further, as cheese has to be dehydrated for observation with conventional scanning electron microscopy, the actual structure is altered. With cryo-scanning microscopy these steps are not needed, thus the actual 


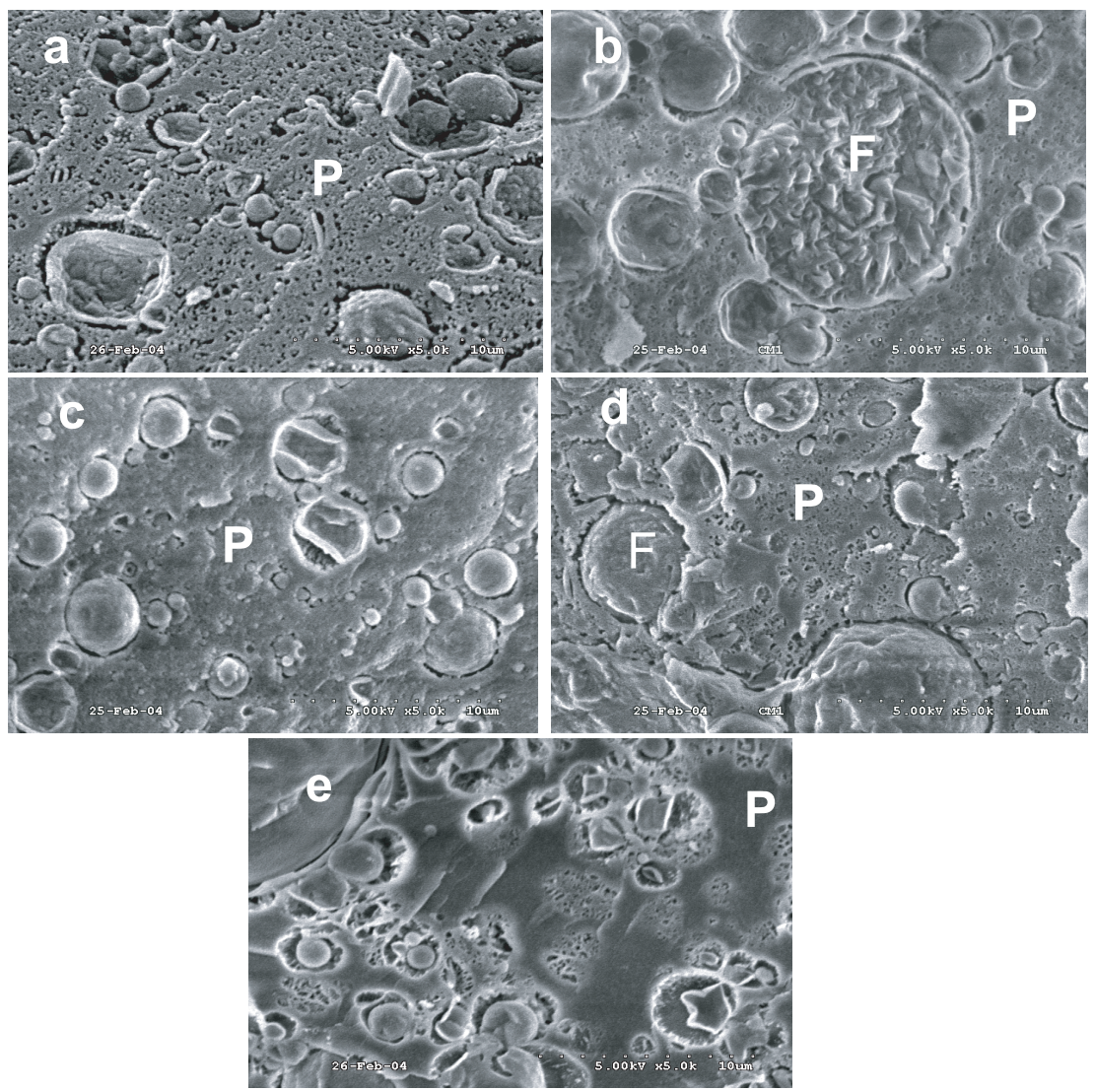

Figure 2. Cryo-scanning electron microscopy images of Process cheese manufactured from milk concentrated by different techniques. $\mathrm{a}=$ control; $\mathrm{b}$ and $\mathrm{c}=$ cheese made from vacuum condensed milk containing $4.5 \%(\mathrm{CM} 1, \mathrm{~b})$ and $6.0 \%(\mathrm{CM} 2, \mathrm{c})$ protein; $\mathrm{d}$ and $\mathrm{e}=$ cheese made from ultrafiltered milk containing $4.5 \%(\mathrm{UF} 1, \mathrm{~d})$ and $6.0 \%(\mathrm{UF} 2, \mathrm{e})$ protein; $\mathrm{P}=$ protein; $\mathrm{F}=$ Fat. Notice the cavities around fat globules.

Table II. Functional and rheological properties ${ }^{1}$ of Process cheese.

\begin{tabular}{lcccccc}
\hline & \multicolumn{5}{c}{ Treatment $^{2}$} & \\
\cline { 2 - 5 } Parameter & $\mathrm{C}$ & UF1 & UF2 & CM1 & CM2 & SEM $^{3}$ \\
\hline Meltability, mm & 74.8 & 69.5 & 65.6 & 67.1 & 62.2 & 4.64 \\
Hardness, kg & 3.9 & 8.5 & 9.9 & 6.3 & 9.1 & 1.73 \\
Free oil, \% & $14.3^{\mathrm{d}}$ & $15.1^{\mathrm{c}}$ & $16.8^{\mathrm{b}}$ & $16.2^{\mathrm{b}}$ & $18.9^{\mathrm{a}}$ & 0.50 \\
Viscosity, cp & 557 & 855 & 1043 & 867 & 1208 & 150.0 \\
\hline
\end{tabular}

a,b,c,d Means in the same row without common superscripts are significantly $(P \leq 0.05)$ different. Means with no superscripts do not have significant interaction between method and level of concentration. ${ }^{1}$ Acharya and Mistry [2]. Mean of six replicates.

2 Treatment: $\mathrm{C}=$ Control; UF1 $=45 \mathrm{~g} \cdot \mathrm{kg}^{-1}$ protein ultrafiltered milk; UF2 $=60 \mathrm{~g} \cdot \mathrm{kg}^{-1}$ protein ultrafiltered milk; $\mathrm{CM} 1=45 \mathrm{~g} \cdot \mathrm{kg}^{-1}$ protein condensed milk; $\mathrm{CM} 2=60 \mathrm{~g} \cdot \mathrm{kg}^{-1}$ protein condensed milk.

${ }^{3} \mathrm{SEM}=$ Standard error of means. 

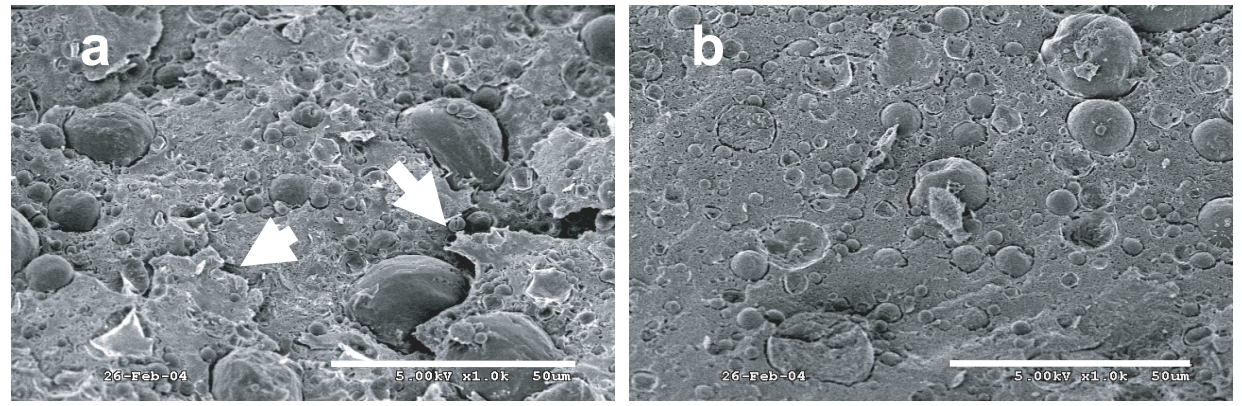

Figure 3. Overall microstructure of the firmest (UF2, a) and softest $(\mathrm{CM} 1, \mathrm{~b})$ cheese as observed by cryo-scanning electron microscopy. Arrows point to regions where fractures in the protein network are apparent.
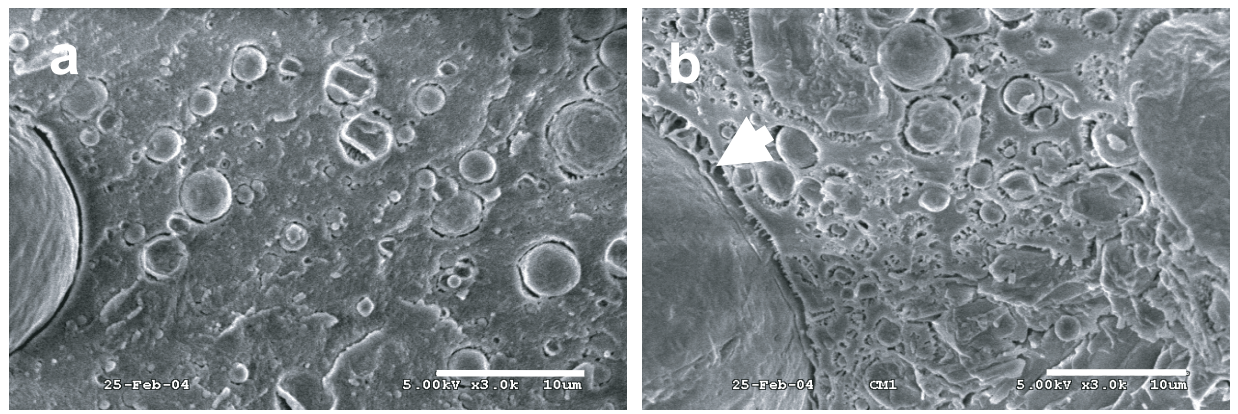

Figure 4. Microstructure of Process cheese made from milk concentrated by vacuum condensing - CM2 (a) - and ultrafiltration - UF1 (b). Arrow points to appendages connecting fat globules with protein network.

structure of cheese is viewed. Fat globules were clearly evident in all cheeses (Figs. 24) and could be distinguished from voids. It was interesting to note that fat globules in all cheeses were surrounded by narrow cavities. It is probable that the cavities around fat globules formed due to differences in thermal expansion/contraction between fat and water during freezing and etching. However, fluorescence microscopy observation of unfrozen specimen confirmed the presence of such cavities (data not shown). This indicated that cavities are not artifacts resulting from the microcopy technique. Neither the size of the cavities around fat globules nor the size of the fat globules seemed to be the key factors affecting the level of free oil. Appendages connecting fat globules to protein network were seen in cheese containing low amounts of free oil (compare UF1 with CM2 in Fig. 4). This suggests that the protein in UF1 cheese may have better emulsifying properties than in CM2 cheeses.

The continuous less rigid protein structure with good emulsifying properties (the presence of appendages connecting protein network to fat globules) produced cheese with increased meltability.

\section{CONCLUSION}

Cryo-SEM is a useful technique for studying microstructure of Process cheese. It allowed the study of porosity and distribution 
of fat globules within the protein network in cheese. Because of the fully hydrated state of cheese specimens observed with cryo-SEM, the microstructure data could explain the physical and functional properties previously reported. This study demonstrated that the microstructure of pasteurized Process cheese is clearly affected by the micro-environment of cheese, which in turn, is affected by the use of vacuum condensing and ultrafiltration for manufacturing the base Cheddar cheese.

Acknowledgement: The authors gratefully acknowledge the assistance of Gib Ahlstrand of the University of Minnesota and CBS Imaging Center for assistance with cryo-scanning electron microscopy.

\section{REFERENCES}

[1] Acharya M.R., Mistry V.V., Comparison of effect of vacuum condensed and ultrafiltered milk on Cheddar cheese, J. Dairy Sci. 87 (2004) 4004-4012.

[2] Acharya M.R., Mistry V.V., Effect of vacuum-condensed or ultrafiltered milk on pasteurized Process cheese, J. Dairy Sci. 88 (2005) 3037-3043.

[3] Caric M., Gantar M., Kalab M., Effect of emulsifying agents on the microstructure and other characteristics of process cheese - a review, Food Microstruct. 4 (1985) 297-312.

[4] Hassan A.N., Frank J.F., El Soda M., Observation of bacterial exopolysaccharides in dairy products using cryo-scanning electron microscopy, Int. Dairy J. 13 (2003) 755-762.

[5] Joshi N.S., Muthukumarappan K., Dave R.I., Effect of calcium on microstructure and meltability of part skim mozzarella cheese, J. Dairy Sci. 87 (2004) 1975-1985.

[6] Raval D.M., Mistry V.V., Application of ultrafiltered sweet buttermilk in the manufacture of reduced fat Process cheese, J. Dairy Sci. 82 (1999) 2334-2343.

[7] Serp D., Mueller M., von Stockar U., Marison I.W., Low-temperature electron microscopy for the study of polysaccharide ultrastructures in hydrogels. I. Theoretical and technical consideration, Biotechnol. Bioeng. 79 (2002) 243-252.

[8] Sutheerawattanonanonda M., Fulcher R.G., Martin F.B., Bastian E.D., Fluorescence image analysis of Process cheese manufactured with trisodium citrate and sodium chloride, J. Dairy Sci. 80 (1997) 620-627. 